www.jmscr.igmpublication.org Impact Factor 5.244

Index Copernicus Value: 5.88 ISSN (e)-2347-176x ISSN (p) 2455-0450 crossref DOI: http://dx.doi.org/10.18535/jmscr/v4i5.44

Journal Of Medical Science And Clinical Research

\title{
Etiological Spectrum of Acute Gastroenteritis in Children Less Than 5 Years of Age with Special Reference to Norovirus (Original Article)
}

\author{
Authors \\ Dr Suneeta Meena ${ }^{1}$, Dr. Anita Chakravarti ${ }^{2}$, Dr Beena Uppal ${ }^{3}$, Dr K.Rajeshwari ${ }^{4}$ \\ ${ }^{1}$ Junior Resident, Microbiology MBBS \\ ${ }^{2}$ Director Professor Microbiology, MD, MNAMS, FIMSA \\ ${ }^{3}$ Director Professor Microbiology, MD \\ ${ }^{4}$ Professor Pediatrics, MD
}

Department of Microbiology, Maulana Azad Medical College \& Associated Lok Nayak Hospital, New

Delhi, India, Pin-110002

Corresponding Author

Dr Anita Chakravarti

Director Professor Microbiology, 79, South Park Apartment, Kalkaji, New Delhi -110019, India.

Phone: +91-11-23239271(Ext.167), Fax: +91-11-23235574

Email: anitachakravarti@gmail.com

\begin{abstract}
To clarify the infectious etiology of acute gastroenteritis in children less than 5 years of age, we conducted a 1-year prospective case-control study. Stools from 150 children with diarrhea and 150 age-matched controls admitted in the hospital for illness involving system other than that of gastrointestinal tract were examined, and their parents were interviewed regarding concerning symptoms. Samples were investigated for parasitic enteropathogens using microscopic examination and bacterial enteropathogens using conventional culture techniques. ELISA was performed for Rotavirus, adenovirus, astrovirus and norovirus were detected by PCR. Overall, a potential pathogen was found in $56.6 \%$ of the cases and $4 \%$ of controls.. The results indicated that noroviruses (4\%) were less common than rotaviruses(24.6\%), EPEC (4.6\%), and V.Cholerae(4\%) but more frequent than astroviruses (2.6\%), adenoviruses(3.3\%), Giardia lambia(2\%) and Shigella spp.(1.3\%). In our study it was found that acute gastroenteritis in children less than 5 years is due to viral etiology, where Rotavirus was predominant cause which points towards the need for a vaccine for this pathogen. While EPEC, Vibrio cholerae and Shigella represent the bacterial etiology of pediatric acute gastroenteritis. The role of norovirus as a emerging pathogen responsible for acute gastroenteritis in children needs to be assesed further.
\end{abstract}

Keywords: etiology, acute gastroenteritis, children, norovirus 


\section{INTRODUCTION}

Acute gastroenteritis is a common cause of childhood morbidity and mortality in children younger than 5 years of age especially in developing countries. In many hospitals in developing countries lacking clinical microbiology laboratories, the cause of acute gastroenteritis remains unknown. Although acute gastroenteritis is seen in all age groups but etiology and clinical course vary with age. Many different pathogens have been found in the stools of children with gastroenteritis. There are many viral, bacterial and parasitic causes of acte gastroenteritis of which viruses are the leading cause in children. Among viruses rotavirus has received considerable attention because it causes more severe clinical symptoms compared with other enteric viruses. But recently the importance of norovirus infection is gradually rising (1). Moreover, introduction of rotavirus vaccine, the incidence of rotavirus infection in patients hospitalized with diarrhea is estimated to have decreased. Knowledge about the role of norovirus in pediatric gastroenteritis in developing countries has been limited by the lack of sensitive and specific diagnostic techniques. Since the introduction of PCR methodologies, several studies have shown that $\mathrm{NoV}$ is an important pathogen causing endemic gastroenteritis in young children, with infection rates from 7 to $22 \%{ }^{(2)}$.

Knowledge on the epidemiology of $\mathrm{NoV}$ infections in India is limited ${ }^{(3,4,5)}$. A study from Vellore, South India conducted in children admitted to the hospital and children in the community has reported $15.1 \%$ and $6.6 \% \mathrm{NoV}$ prevalence respectively ${ }^{(4)}$. An earlier report on the sporadic cases of acute gastroenteritis from Pune, western India has described the prevalence of NoVs in $12.5 \%$ cases ${ }^{[5]}$. The present study was designed to study the prevalence of norovirus alone and in co-infection with other enteropathogens, in children less than 5 years of age hospitalised for gastroenteritis

\section{MATERIAL AND METHODS}

The present study was conducted in the Department of Microbiology in conjunction with the Department of Pediatrics, Maulana Azad Medical College and associated Lok Nayak Hospital, New Delh, India.

\section{STUDY DESIGN}

It was a prospective cross-sectional case control study conducted on children admitted in the diarrhea ward of Lok Nayak Hospital, New Delhi. A total of 300 faecal specimens were collected during the study period from September 2010 to September 2011, of which, 150 were from acute watery diarrhea cases (under 5 years) admitted in the diarrhea ward, Lok Nayak Hospital, and an equal number were also collected from asymptomatic children admitted for other illness. Patient information and clinical details were recorded in diarrhea case/ control reporting forms . Informed consent was also obtained from parents or child guardians.

Specimen were collected in $<24 \mathrm{hrs}$ of admission and transported to Microbiology laboratory of Maulan Azad Medical College at $4^{\circ} \mathrm{C}$. All specimens were examined microscopically for the presence of leukocytes, erythrocytes, and parasites by using a saline and-iodine wet preparation. Specimens for bacteriological culture were inoculated into appropriate media on the day of collection and further identification was done as per standard bacteriological techniques. Specimens for viral detection stored at $-70^{\circ} \mathrm{C}$ until further processed. commercial immunoassays were used according to manufacturer's instructions to detect specific antigens from group A rotaviruses, adenoviruses type 40 and 41 , and astroviruses. Norovirus was detected by RT$\mathrm{PCR}^{(2)}$

\section{RESULTS}

Overall a potential pathogen was found in $56.6 \%$ of the cases as compared to $4 \%$ in controls. Among all samples tested virus was isolated from $34 \%$ controls as compared to $4 \%$ in controls, 
bacterial pathogens were isolated from $10 \%$ of the cases and parasitic pathogens from $2 \%$ of the cases, the later two could not be isolated from controls.

Rotavirus (24.6\%) was the most common pathogen detected in cases and was the only pathogen detected in controls, consequently had the highest association with the disease. It was predominant in the children of 7-12months age group, as maximum number(44.6\%) of cases were from the same age group. The relative frequencies of enteropathogens in children of different age groups are shown in table.1. The highest isolation rate of norovirus occurred in 7-12 months age group followed by 13-24 months. Astrovirus (2.6\%)s and adenovirus(3.3\%) were isolated from children less than 24 months. Bacterial isolates were isolated from all the age groups.

On the whole, viral pathogens $(34.6 \%)$ were more significant etiology (p-value<0.05) than bacterial pathogens $(10 \%)$ in all the age groups. However, they were statistically significant in 7-12 months age group.

Mixed infections (table.2) were found in 10\% of the cases. Viral-viral co-infections $(n=7)$ were almost equivalent to viral-bacterial co-infections. Rotavirus ( $\mathrm{n}=13$ ) was the most common pathogen to be found in co-infection with both bacterial $(n=7)$ and viral pathogens $(n=8)$. Co-infection of norovirus with rotavirus was seen in two cases and from one case three viruses namely rotavirus, adenovirus and astrovirus were isolated.

As per modified vesikari score (6) rotavirus gastroenteritis was more severe as compared to norovirus. Overall, viral and bacterial gastroenteritis were comparable in severity. Mixed infections were variable in severity from mild to severe with no discernible pattern of severity as compared to single pathogens as shown in table.3.

The seasonal distribution of acute gastroenteritis as per enteropathogen showed that viral infection occurred all year round with a distinctive peak for both norovirus and rotavirus in months of November and December. Bacterial pathogens were isolated throughout the year but most of the
Enteropathogenic E.Coli related cases predominated from April till August. Vibrio Cholerae was found singly and in association with other pathogens in rainy season. Mixed infections also had special prediction for rainy season

\section{DISCUSSION}

Viral and bacterial pathogens were identified in about $57 \%(n=85)$ of the specimens. There are several factors which might explain why no causative agent was detected in the remaining specimens $43 \% \quad(n=81)$. Organisms may have escaped detection due to the low numbers present in specimens, the delay between the onset of symptoms and collection of specimens, transport loss due to overgrowth by physiological stool flora, or more sensitive laboratory assays. In some cases, patients may have been infected by enteropathogens that were not included in the diagnostic scope, like sapoviruses, incidence of which has been found to be as high as $5.1 \%$ in hospitalized children less than 5 years in vellore (4). The same organism was identified in $10.7 \%$ of the samples in children less than 10 years in a study from Delhi ${ }^{(7)}$. Finally, diarrhea may occur as a symptom in non-infectious illnesses. Further research is urgently needed to refine the methods used for the efficient detection of known causative agents of acute gastroenteritis and to discover as yet unknown pathogens.

The predominant age group in our study was in the range of 7-12 months (44.7\%) followed by age group ranging 13-24 months (34.7\%). The age wise distribution of cases showed that $79 \%$, a statistically significant number of cases are in the age group of 7-24 months. It appeared that infants below 6 months of age were initially protected to some extent by maternal antibodies and after 2 years they seem to have acquired adequate immunity against severe gastroenteritis.

This study confirms worldwide studies implicating group A rotaviruses as the single most important cause of severe diarrhea in young children ( 0 to 5 years) admitted to hospitals in developed and developing countries. 
Recently, the importance of noroviruses as the second cause of viral gastroenteritis has been reported by many authors $(4,5,7,8,9)$. The disease burden of norovirus has been well documented for developed countries, however there is little information about this virus in the Indian subcontinent. Studies on norovirus associated acute gastroenteritis in India are limited. A study from Vellore, south India conducted in children admitted to the hospital and in the community reported $15.1 \%$ and $6.6 \%$ prevalence respectively (4). In a study from Pune it was reported that detection rate in children less than 7 years was $10.7 \%$. In the same study prevalence of norovirus in Nagpur was found to be $6.3 \%$ which is quite less then overall prevalence reported from western India. An earlier report on the sporadic cases of acute gastroenteritis from Pune has described the prevalence of norovirus in $12.5 \%$ cases ${ }^{(5)}$. In a previous study from Delhi ${ }^{(7)}$ on molecular characterization of norovirus prevalence of was found to be $10 \%$ in children less than 10 years while, in the present study detection rate of norovirus was $4 \%$ in cases in children less than 5 years. This contrasts with earlier reports of norovirus gastroenteritis and indicates that norovirus disease is less prevalent in this part of Delhi. A recent study from vellore (10) demonstrates that higher detection of noroviruses can be obtained by either using multiple primer sets or using a sensitive nested RT-PCR assay. It also demonstrates the differences in primer sensitivity for detection of norovirus in India. The difference in sensitivity and specificity of various primers often lead to difficulties in comparing results from various studies. Indeed in an international collaborative study to compare RTPCR assays for the detection and genotyping of noroviruses from several countries, no single assay stood out as the method of choice and a range of sensitivities in results were seen (11). There is no consensus about the genomic region or the primer sets for the detection of noroviruses worldwide. However, prevalence of norovirus in different studies may vary with the use of different sets of primers. In a study for the detection of noroviruses from Japan ${ }^{(12)}$, it was found that there was no single primer set that could detect all noroviruses and at least three primer pairs were required to detect the virus. This suggested that the use of combination of primer sets could increases the sensitivity of detecting noroviruses, as compared to the use of a single set of primers, in any geographical region. In this study single pair of primer set was used, which could explain low detection rate. Thus, low detection rate in this study could be attributed to use of restricted primers as compared to multiple sets of primers used in studies elsewhere demonstrating high detection rate. Refinement and evaluation of diagnostic techniques is needed to assess the true burden and etiology of diarrheal disease. This is particularly true for noroviruses where virus evolution and introduction of new strains require regular updating of methods, and where one method cannot be uniformly applied in all parts of the world ${ }^{(10)}$.

It is also to be noted that norovirus was not at all isolated from controls which is in contrast with reports of high (6-11\%) asymptomatic carriage of norovirus ${ }^{(4)}$, which could also contribute to low prevalence of norovirus in this region.

This variable prevalence (4-12\%) of norovirus in different parts of India could be attributed to variable climatic and geographic factors. It also suggests that norovirus is mainly responsible for outbreaks and has a limited role in sporadic gastroenteritis. It is likely that the relative role of noroviruses will increase in regions that have incorporated rotavirus vaccines to the National Programs.

Our figures are analogous to prevalence of astrovirus infection that was reported to vary from 3 to $16 \%$ among hospitalized children with diarrhea ${ }^{(13)}$.

The predominance of EPEC (58.3\%) among all bacterial isolates is consistent with previous reports from other developing countries underlining their importance as the main bacterial causes of diarrhea in children aged less than 5 
years and the need to type them in order to know the types that cause diarrhea in our setting ${ }^{(14)}$. The classical poly O1 EPEC serotypes, was isolated in present study an it was the second most common pathogen indicating is an important cause of diarrheal illness in children.

Viral and bacterial intestinal pathogens could affect either the same or different regions of the gut, and their effects would be enhanced. Mixed infections have been described previously in children with acute gastroenteritis, but few data on the role of noroviruses in dual infections are available. Further studies must be performed in order to obtain a better understanding of these infections.

Analysis of clinical severity scores, indicated that norovirus gastroenteritis ranged from mild to very severe with maximum cases $(40 \%)$ in the range of moderate severity. It was associated with accompanying fever in $80 \%$ cases and vomiting in $60 \%$ cases. These results are in agreement with the general impression that norovirus infections are associated with fever and vomiting but stands in contrast with the results of chabra et al ${ }^{(15)}$.

Overall, rotavirus was more severe than norovirus gastroenterits although most cases for both viruses are in the range of moderate to severe. The proportion of very severe cases was similar for both viruses. No significant difference was found out for clinical manifestations for the gastroenteritis caused by these two viruses which is in accordance with an earlier study conducted in china $^{(16)}$.

The rotavirus- and norovirus-associated winter peaks found in the present report support the view that rotavirus and norovirus infections exclusively have wintertime seasonality. But, a study from Pune demonstrates increased norovirus activity from months of January ${ }^{(15)}$. It is probable that a single worldwide norovirus seasonal pattern for epidemic and endemic gastroenteritis does not exist as several cofactors may influence virus circulation.

It can be concluded from this study, that rotavirus continues to be topmost cause of acute gastroenteritis in children below 5 years of age, responsible for almost one-fourth of the hospitalizations. Vaccination will go a long way in reducing both morbidity and mortality associated with this organism. Although, norovirus was second most common viral pathogen in children but its prevalence was less as compared to earlier studies, thus, doubting its role as a emerging pathogen in acute gastroenteritis.

\begin{tabular}{|l|l|l|l|l|l|l|l|l|}
\hline \multicolumn{2}{|l|}{ TABLE 1.Agewise Distribution Of Isolated Enteropathogens In Cases } \\
\hline $\begin{array}{l}\text { AGE } \\
\begin{array}{l}\text { GROUP } \\
(\mathrm{months})\end{array}\end{array}$ & $\begin{array}{l}\text { NORO } \\
\text { VIRUS } \\
(\%)\end{array}$ & $\begin{array}{l}\text { ROTA } \\
\text { VIRUS } \\
(\%)\end{array}$ & $\begin{array}{l}\text { ASTR } \\
\text { VIRUS } \\
(\%)\end{array}$ & $\begin{array}{l}\text { ADENO } \\
\text { VIRUS } \\
(\%)\end{array}$ & $\begin{array}{l}\text { EPEC } \\
(\%)\end{array}$ & $\begin{array}{l}\text { VC } \\
(\%)\end{array}$ & $\begin{array}{l}\text { SHIGELLA } \\
\text { SPP. }(\%)\end{array}$ & $\begin{array}{l}\text { GIARDIA } \\
(\%)\end{array}$ \\
\hline $\begin{array}{l}0-6 \\
(\mathrm{n}=13)\end{array}$ & 0 & $3(2.3)$ & $1(7.6)$ & $1(7.6)$ & $2(15.3)$ & $0(0)$ & $0(0)$ & $0(0)$ \\
\hline $\begin{array}{l}7-12 \\
(\mathrm{n}=67)\end{array}$ & $4(5.9)$ & $20(29.8)$ & $2(2.9)$ & $2(2.9)$ & $2(2.9)$ & $2(2.9)$ & $0(0)$ & $2(2.9)$ \\
\hline $\begin{array}{l}13-24 \\
(\mathrm{n}=52)\end{array}$ & $2(3.8)$ & $8(15.2)$ & $1(1.9)$ & $2(3.8)$ & $2(3.8)$ & $1(1.9)$ & $1(1.9)$ & $1(1.9)$ \\
\hline $\begin{array}{l}25-60 \\
(\mathrm{n}=18)\end{array}$ & 0 & $6(37.5)$ & $0(0)$ & $0(0)$ & $1(15.5)$ & $3(16.6)$ & $1(5.5)$ & $0(0)$ \\
\hline $\begin{array}{l}\text { TOTAL } \\
(\mathrm{n}=150)\end{array}$ & $6(4)$ & $37(24)$ & $4(2.6)$ & $5(3.3)$ & $7(4.6)$ & $6(4)$ & $2(1.3)$ & $3(2)$ \\
\hline
\end{tabular}




\begin{tabular}{|l|l|}
\hline \multicolumn{2}{|l|}{ TABLE 2. Mixed Infections } \\
\hline Combination of infectious agents & Number(\%) \\
\hline Norovirus and rotavirus & $2(13.3)$ \\
\hline Rotavirus and adenovirus & $1(6.6)$ \\
\hline Rotavirus and astrovirus & $3(2)$ \\
\hline Rotavirus ,astrovirus and adenovirus & $1(6.6)$ \\
\hline Rotavirus and Enteropathogenic E.Coli & $6(4)$ \\
\hline Rotavirus and V.Cholerae & $1(0.6)$ \\
\hline Rotavirus and Shigella flexneri & $1(6.6)$ \\
\hline Total & $15(10)$ \\
\hline
\end{tabular}

TABLE 3. Seveity Of Diarrhea Related With Isolated Enteropathogens As Per Modified Vesikari Score

\begin{tabular}{|l|c|c|c|}
\hline PATHOGEN & MILD $(\%)$ & MODERATE $(\%)$ & SEVERE $(\%)$ \\
\hline ROTAVIRUS $(\mathrm{n}=37)$ & $7(18.9)$ & $18(48.6)$ & $12(32.4)$ \\
\hline NOROVIRUS(n=6) & $1(16.6)$ & $4(66.6)$ & $1(16.6)$ \\
\hline ASTROVIRUS(n=4) & $2(50)$ & $2(50)$ & 0 \\
\hline ADENOVIRUS $(\mathrm{n}=5)$ & $2(40)$ & $3(60)$ & 0 \\
\hline EPEC $(\mathrm{n}=7)$ & $2(28.5)$ & $2(28.5)$ & $3(42.8)$ \\
\hline V.CHOLERAE $(n=6)$ & $1(16.6)$ & $2(33.3)$ & $3(50)$ \\
\hline SHIGELLA SPP. $(n=2)$ & 0 & $2(100)$ & 0 \\
\hline PARASITES $(\mathrm{n}=3)$ & $2(66.6)$ & $1(33.3)$ & 0 \\
\hline MIXED INFECTIONS $(\mathrm{n}=15)$ & $3(20)$ & $7(46.6)$ & $5(33.3)$ \\
\hline TOTAL $(\mathrm{n}=85)$ & $20(23)$. & $41(48.2)$ & $24(28.2)$ \\
\hline
\end{tabular}

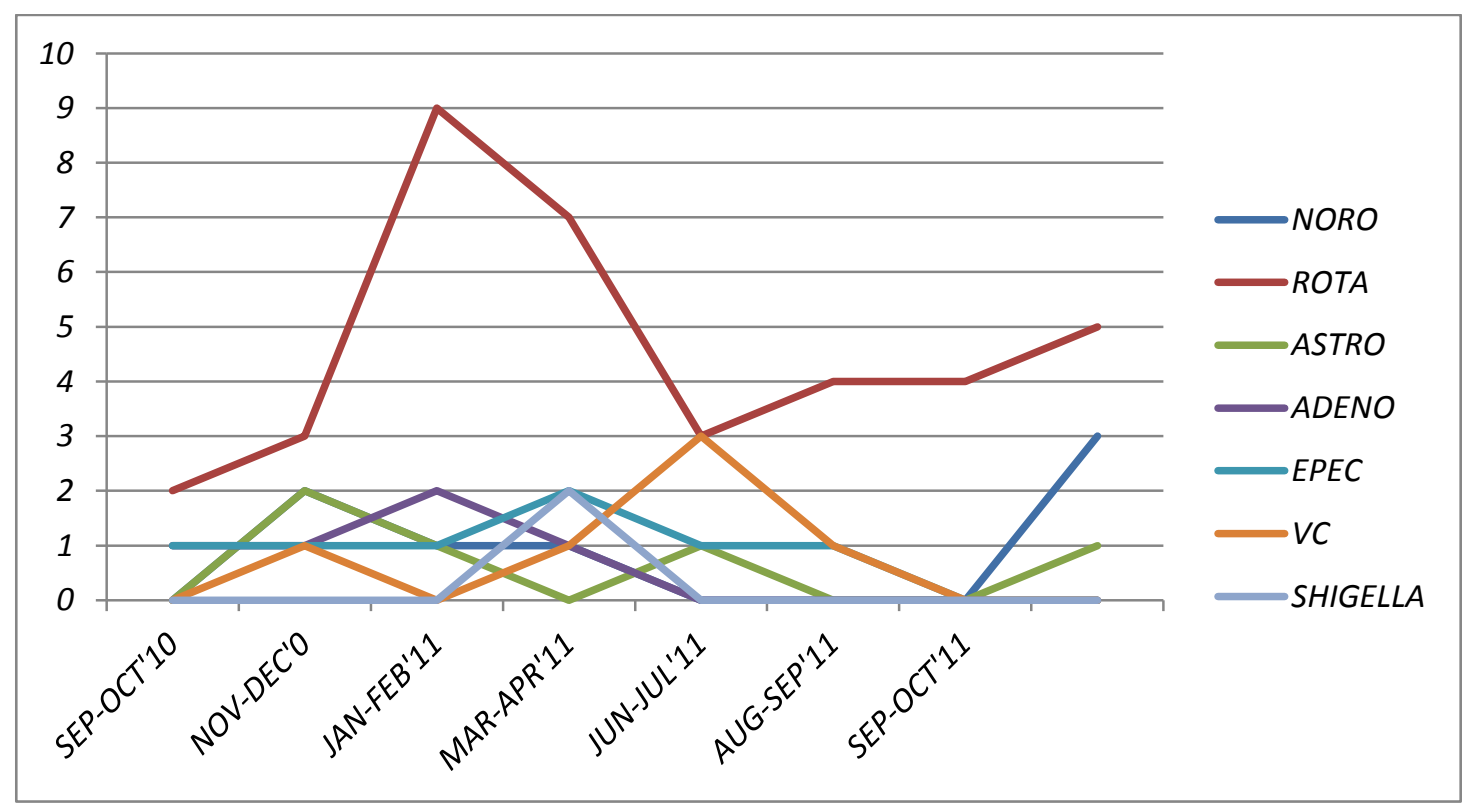

Source of funding: Departmental funding Conflict of interest: None

\section{REFERENCES}

1. Atmar RL, Estates MK. Diagnosis of noncultivable gastroenteritis viruses, the human calciviruses. P. Clin Microbiol Rev 2001;14:15-37

2. Ramani S, Kang G. viruses causing childhood diarrhea in the developing world. Curr Opin Infect Dis 2009;22:47782 
3. Girish R, Broor S, Dar L, Ghosh D. Food borne outbreak caused by a Norwalk-like virus in India. J Med Virol 2002;67:603-7

4. Monica B, Ramani S, Banerjee I, Primrose B, Iturriza-Gomara M, Brown DW, Fathima M, Prabhakar D, Moses JJ, kang G. Human calciviruses in symptomatic and asymptomatic children in vellore, south india. J Med Virol may 2007;79(5):544-51

5. Chhabra P, Chitambar SD. Norovirus genotype IIb associated acute gastroenteritis in India. J Clin Virol. 2008 Aug; 42(4):429-32

6. Freedman SB, Eltorky M, Gorelick M. Evaluation of a gastroenteritis severity score for use in outpatient settings. Pediatrics. 2010 Jun;125(6):1278-85.

7. Rackakonda G, Choudekar A, Parveen S, Bhatnagar S, Patwari A, Broor S. Genetic diversity of noroviruses and sapoviruses in children with acute gastroenteritis in New Delhi, India. J Clin Virol 2008;43:42-48

8. Román E, Wilhelmi I, Colomina J, Villar J, Cilleruelo ML, Nebreda V, Del Alamo M, Sánchez-Fauquier A. Acute viral gastroenteritis: proportion and clinical relevance of multiple infections in Spanish children. J. Med. Microbiol. 2003;52:43540.

9. Klaus R, Ralf I, Thomas W, Andrew SK,Louis A, Eiman S, Andrea DM, Peter Z, Felicia AS, Francis D, Stephen D, Rowland NO, Eckart S, Ulrich B. Acute childhood diarrhoea in northern Ghana: epidemiological, clinical and microbiological characteristics. BMC Infectious Diseases 2007; 7:104-14.

10. George S, Menon VK, Ramani S, Kang G. Comparision of primers for the detection of genogroup II noroviruses in India. Indian J Med Microbiol 2012;30(1);24-9

11. Vinje J, Vennema H, Maunula L, von Bonsdorff $\mathrm{CH}$, Hoehne M, Schreier E, et al. International collaborative study to compare reverse transcriptase PCR assays for detection and genotyping of noroviruses. J Clin Microbiol 2003;41:1423-33.

12. Honma S, Nakata S, Kinoshita-Numata K, Kogawa K, Chiba S. Evaluation of nine sets of PCR primers in the RNA dependent RNA polymerase region for detection and differentiation of members of the family Caliciviridae, Norwalk virus and Sapporo virus. Microbiol Immunol 2000;44:411-9

13. Bhattacharya R, Sahoo GC, Nayak MK, Ghosh S, Dutta P, Bhattacharya MK, Mitra U, Gangopadhyay D, Dutta S, Niyogi SK, Saha DR, Naik TN, Bhattacharya SK, Krishnan T: Molecular epidemiology of human astrovirus infections in Kolkata, India. Infect Gen Evol 2006;6:425-435

14. Vargas M, Gascon J, Casals C, Schellenberg D, Urassa H, Kahigwa E, Ruiz J,Vila $J$ Etiology of diarrhoea in children less than five years of age in Ifakara, Tanzania. Am J Trop Med Hyg 2004;70:536-9

15. Chhabra P, Dhongade RK, Kalrao VR, Bavdekar AR, Chitambar SD Epidemiological, clinical, and molecular features of norovirus infections in western India.J Med Virol. 2009 May;81(5):922-32.

16. Deng L, Jia LY, Qian Y, Chen DM, Zhang Y, Zhang YL Comparative analysis on clinical manifestations for gastroenteritis caused by norovirus and rotavirus Zhonghua Liu Xing Bing Xue Za Zhi. 2009 Apr;30(4):398-401 